\title{
Who calls it? Actors and accounts in the social construction of organizational moral failure
}

\begin{abstract}
In recent years, research on morality in organizational life has begun to examine how organizational conduct comes to be socially constructed as having failed to comply with a community’s accepted morals. Researchers in this stream of research, however, have paid little attention to identifying and theorizing the key actors involved in these social construction processes and the types of accounts they construct. In this paper, we explore a set of key structural and cultural dimensions of apparent non-compliance that enable us to distinguish between four categories of actors who engage in constructing the label of moral failure: dominant insiders, watchdog organizations, professional members, and publics. The analysis further clarifies which category of actor is more likely to succeed in constructing the label of moral failure under which circumstances, and what accounts they are likely to use, namely: scapegoating, prototyping, shaming and protesting.
\end{abstract}

Keywords: Account; Actor; Label; Legitimacy; Moral Failure; Morality; Social construction; Surveillance 
Who Calls it?

\section{Who calls it? Actors and accounts in the social construction of organizational moral failure}

High profile events such as Volkswagen's emissions cheating scandal or the Petrobras corruption scandal have fueled continued interest in organizational moral failure. Defined as noncompliance with the moral norms or expectations of a community, organizational moral failure is a major societal and organizational problem in that it leads to negative social consequences for those impacted by the failure, and trust and legitimacy challenges for perceived perpetrators and those associated with them (Ashforth et al., 2008; Janney and Gove, 2017; Jonsson et al., 2009; Vergne, 2012; Zavyalova et al., 2012).

An important development in our understanding of organizational moral failure has been the emergence of more actor-centered analyses that focus on how organizational conduct comes to be socially constructed as moral failure (Cooper et al., 2013; Granovetter, 2007; Greve et al., 2010; Kuhn and Ashcraft, 2003; Logue and Clegg, 2015; Palmer, 2012; Shadnam and Lawrence, 2011). This stream of research has shown that the morality of organizational conduct is often understood in multiple ways. It has also highlighted the contests among interested actors with respect to whether organizational conduct should be understood as moral failure or as something else such as normal, trouble, accident, incompetence, or principled resistance (see Morrill et al., 2003; Wiesenfeld et al., 2008).

A key theme in this research has been the differentiated strategies and roles of specific kinds of actors, including regulatory agencies (Bertels et al., 2014; Palmer, 2012; Short and Toffel, 2010), public media (Benediktsson, 2010; Piazza and Perretti, 2015), and witnesses to the organizational conduct (MacLean, 2008; Miceli et al., 2008), as well as the focal organizations involved in the potential moral failure (Bartunek et al., 2006; Zavyalova et al., 2012). Some scholars have also considered larger sets of actors (Lange and Washburn, 2012; Prechel and Morris, 2010), sometimes under the banners of stakeholders (Barnett, 2014; 
Kaptein, 2008) or institutional actors (Gabbioneta et al., 2013; Shadnam and Lawrence, 2011).

However, despite the attention to specific and generalized sets of actors, there is no integrative framework that enables us to determine which actors are likely to be successful in constructing an action as organizational moral failure. That is, we know that the process of socially constructing organizational conduct as moral failure "takes a village, including several nontraditional players” (Dyck et al., 2010, p. 2213), but we lack a catalogue of the people in the village, an understanding of who in the village gets to "call” moral failure, and when and how they get to do so. This lack of an integrated understanding of the actors and accounts involved in the social construction of organizational moral failure has seriously hindered the further development of the literature because extant research has no way of explaining the contingencies under which particular actors are enabled (or constrained) in constructing moral failure. Therefore, the social construction of organizational moral failure appears to be idiosyncratic or arbitrary without any clear understanding of the contextual embeddedness of actors and their accounts of moral failure.

In this paper, we develop a contingency-based, actor-centered framework for understanding the social construction of organizational moral failure. We draw on the literature on surveillance (Sewell, 1998, 2012; Sewell and Wilkinson, 1992) to situate moral failure in the structures that guard and recreate morals of a community. This allows us to differentiate actors based on their position and role in these surveillance structures. The structural position of actors, however, does not necessarily translate into their credibility and drive to announce that an organizational conduct is a moral failure. Therefore, we supplement the structural dimension with a cultural dimension drawing on the literature on the sources of moral legitimacy (Deephouse and Suchman, 2008; Meyer and Scott, 1983; Suchman 1995). This allows us to differentiate between contexts where those inside professions are most 
important in determining and articulating whether an action represents a congruence with norms (because the source of moral legitimacy is the profession) and those where outsiders are more important (since the source of moral legitimacy is congruence with more general social values). Accordingly, we distinguish between four categories of actors who engage in constructing the label of moral failure - dominant insiders, watchdog organizations, professional members, and publics - and four types of accounts that such actors are likely to use in constructing organizational moral failure in these contexts, namely scapegoating, prototyping, shaming, and protesting.

Our analysis makes five key contributions to the existing research. First, we introduce a typology of actors that advances the extant literature by giving a name and face to the abstract notion of embedded agency at play in the social construction of organizational moral failures. Second, our analysis sheds light on new, unexamined aspects of the social processes that precede or follow the social construction of moral failure. Third, we provide a unique contingency framework for constructions of moral failure that enables researchers to predict whether and by whom these failures are likely to be called out. Fourth, we offer a typology of accounts of moral failure, which helps unpack the relationships among particular discursive constructions of organizational morality, the capabilities of actors, and the structure of circumstances. Finally, we provide a basis for analyzing the social construction of moral failure under conditions of institutional pluralism, and to explain and predict which types of actors are likely to confront one another in such conditions.

We present our arguments in four main sections. First, we develop our conception of moral failure and the theoretical questions that guide the paper. Second, we argue that the social construction of moral failure involves two intersecting processes - the construction of organizational conduct as noncompliance, and the construction of it as immoral - and consider the conditions that might lead different kinds of actors to engage in each process. 
Third, we examine how the intersection of these processes suggests four potential paths to the social construction of moral failure, each led by a distinct set of actors. Fourth, we discuss each of the five contributions introduced above, exploring how our arguments make that contributions and its significance for existing research. We conclude the paper with a brief summary and a discussion of important scope conditions for our arguments.

\section{Moral failure in organizational life}

While the term “moral failure” appears relatively rarely in organizational research (for exceptions, see Brown and Jones, 2000; Goodstein and Wicks, 2007), there exists a wide array of studies examining organizational conduct that falls short of accepted moral norms or expectations. These studies are scattered under different banners such as deviance, corruption, misconduct, unethical behavior, and counterproductive behavior. There are of course important differences in terms of how each of these is conceptualized and operationalized, and so to avoid confusion and inconsistency, we define moral failure in a way that clearly marks its territory.

In standard English, “failure” refers to the “omission of occurrence or performance, specifically a failing to perform a duty or expected action” (Merriam-Webster 2006 [emphasis in the original]). Thus, "moral failure” suggests a failure to perform a moral duty, and so has two important elements: (1) a failure to comply with some social expectation, and (2) that failure being considered immoral. Taking a social constructionist perspective here implies that both elements are always embedded in and mediated by social processes of meaning making.

A failure to comply with social expectations is not an empirical fact that automatically and unequivocally reveals itself in the understanding of the observer; rather, it is a collective understanding that is constructed out of the inputs, evaluations, and influences of many actors. Consider the case of the Stafford Hospital scandal: not changing the bed sheets of 
hospital patients on a regular basis, for instance, could be understood as standard procedure in some situations and a failure to abide by social expectations in other situations. Social expectations may or may not be codified into laws; they may exist as norms or rules that operate outside of legal strictures. In either case, though, a failure to comply with social expectations, legal or otherwise, depends on a social process through which that failure is constructed as such.

Similarly, immorality is not an inherent quality of failing to comply with social expectations; rather, for a failure to be considered immoral there needs to be a set of actors who judge and establish the failure as immoral. Failing to comply with standards of bed-sheet changing in hospitals, to continue the above example, could be considered resistance to overly-stringent cleaning procedures, unintentional oversight, or poor performance. For this failure to be considered immoral, on the other hand, it would need to be constructed as such by actors who portray it as a lack of reasonable care, cruelty to patients, or other accounts along those lines. Again, this may or may not intersect with the legality of an act. In a wellestablished conception of the relationship between ethics and legality, the two exist as overlapping spheres in a Venn diagram (see Treviño and Nelson, 2007). From a social constructionist perspective, we interpret this diagram as showing that although actions may be socially constructed as both illegal and unethical, these represent separate (though not independent) processes, such that acts might also be socially constructed as immoral and not illegal (and vice versa).

Accordingly, we define "moral failure" as a collective understanding that is socially constructed and conveys the two elements of noncompliance and immorality. The social construction of moral failure then is the middle stage in the chain of events associated with failures of organizations with respect to morals (See Figure 1). The stage just preceding the social construction of moral failure comprises the processes that lead individuals and 
organizations to engage in morally questionable conduct. Subfields such as organizational misconduct (Greve et al., 2010), unethical behavior (Treviño et al., 2014), corruption (Ashforth et al., 2008), and studies on antecedents of deviance (Bennett and Robinson, 2003) often focus on this stage, as they examine the precipitating conditions and the dynamics associated with organizational actors engaging in conduct that might be labeled as moral failure. On the other hand, the stage following the social construction of moral failure comprises the processes that organizations engage in to deal with the moral failure, such as purifying their image from the attributed taint, regaining stakeholders' trust, and sometimes even restructuring the field (Durand and Vergne, 2015; Vergne, 2012). The empirical studies of this stage, for instance, have documented how managers work to overcome the organizational moral failure and even leverage that labeling for bringing about positive outcomes in their organization (Tracey and Phillips, 2016). These processes are often examined in association with crisis and scandal management (De Maria, 2010; Kuhn and Ashcraft, 2003), trust repair (Eberl et al., 2015; Gillespie et al., 2014), stigma (Durand and Vergne, 2015; Piazza and Perretti, 2015), organizational rehabilitation (Bertels et al., 2014; Goodstein et al., 2014), and responses to deviance (Sharkey, 2014; Waegel et la., 1981). Thus, the social construction of moral failure, as we conceive it, represents the middle stage, comprising the processes through which organizational conduct is socially constructed as moral failure.

It should be noted that there is no impermeable boundary between the three stages and there are some studies in the aforementioned subfields that extend the label of deviance, stigma, corruption, or misconduct across the three stages (e.g. Azoulay et al., 2017; Carberry et al., 2018; Cohen and Dromi, 2018; MacLean, 2008; MacLean and Behnam, 2010; Roulet, 2015). There are also studies that focus on illegal behavior in organizations (e.g. Daboub et al., 1995; Mitchell et al., 1996), which is overlapping though not the same as moral failure. 
Regardless of the employed label, so far as we see the two elements that constitute moral failure - noncompliance and immorality - we incorporate those studies in our discussion of organizational moral failure. Our aim in the remainder of this section is to explore organizational moral failure in terms of social construction with a view to surfacing critical structural and cultural dimensions, namely forms of surveillance and degrees of professionalization.

\section{Insert Figure 1 about here}

\section{Social construction of noncompliance}

From our perspective, noncompliance is not a characteristic inherent to some specific organizational conduct, but rather the assignment of a discursive category to the conduct through the work of interested actors. Our focus is on understanding when and why different kinds of actors will succeed in constructing organizational conduct as noncompliance.

The core structural dimension that affects who will be more likely to engage in constructing an instance of noncompliance is the kind of surveillance through which actors might become aware of noncompliance. Surveillance involves "sensing, measuring, storing, processing, and exchanging information and intelligence about the environment” (Gandy, 1989, p. 62). Surveillance, in this broad sense of the term, is at the core of all control mechanisms that aim to regulate conduct and ensure compliance with a given order. That is why the maintenance of institutions depends on some form of surveillance, in order to ensure the "potential for noncompliance to be registered by systems which will automatically punish, shame, embarrass, or penalize” (Lawrence, 2008, p. 179). While the existence of surveillance does not guarantee that every single case of noncompliance is detected, and there are studies of how some organizations fool the surveillance systems (e.g. Dey and Teasdale, 2016), nonetheless surveillance plays an integral role in the self-policing character of institutions in a community. 
Morals constitute a salient set of institutions for every human community and their persistence depends on the mechanisms of surveillance for detecting instances of noncompliance and punishing the perpetrators. This has been documented even in extreme cases of highly homogeneous communities where most morals are widely shared and deeply taken-for-granted. For example, Miller’s study of the Basel Mission, which “was founded in the early $19^{\text {th }}$ century to educate missionaries and establish evangelical outposts in various parts of the world", shows that they had "formalized procedures of mutual surveillance ... that insulated them from being corrupted by the secular world” (Scott, 2014, p. 155-156 summarizing Miller, 1994). So with respect to the morals of a community, there is always a surveillance mechanism in place for detecting any conduct that can potentially be viewed as a case of noncompliance with those morals (Shadnam and Lawrence, 2011).

Forms of surveillance. A useful set of categories in thinking about surveillance triggering the social construction of noncompliance by different actors is Sewell's (1998) distinction between "horizontal” and "vertical” surveillance. Horizontal surveillance involves the dissemination of information about an actor's behavior or performance to other actors operating at a similar level in an organization or community (Barker, 1993; Sewell, 1998; Tompkins and Cheney, 1985), and so will be more likely connected to the construction of noncompliance by non-elite actors. In an organizational community, horizontal surveillance might involve peer-to-peer informal communication, private or public media, such as newspapers and websites, and broadly distributed communications or reports from third parties such as associations or auditors. In contrast, vertical forms of surveillance direct information upward to hierarchically superior actors in a community or organization (Sewell, 1998), and so will be more important to the construction of noncompliance by elites. In organizational communities, vertical surveillance might occur through formal hierarchical reporting, exclusive informal networks, or impersonal, role-based or technological systems. 
Therefore, the forms of surveillance available to actors significantly influence whether elite or non-elite actors are more likely to engage in constructing some organizational conduct as noncompliance.

The distinction between elite and non-elite actors in a community refers to an institutionally specific set of attributes that lend certain actors power and privilege in a particular domain (Lawrence and Suddaby, 2006; Selznick, 1957, 1992). The role of elites in maintaining institutions by identifying and addressing instances of noncompliance has been broadly identified (Holm, 1995; Leblebici et al., 1991), as has their engagement in policing and demonizing instances of noncompliance (Angus, 1993; Fox-Wolfgramm et al., 1998). Selznick (1992) argues that the role of elites in maintaining the integrity of institutions can be a positive one:

"the social function of value-centered elites is to elaborate, nurture, and defend particular skills, standards, and ideals ... [and] [i]nsofar as this function is performed well, the community benefits,” (Selznick, 1992, p. 499). Non-elite actors can also play an important role, however, in constructing organizational conduct as noncompliance. This role is evident in the literature on populist social movements that documents the role of non-elite actors in calling attention to and demanding social change based on noncompliance by corporations and government agencies (Crossley, 2002; Nielsen, 2000; Rao, 1998). The key determinant, we suggest, in whether elites or non-elites will be more likely to act in this way will be the form of surveillance in operation.

\section{Social Construction of Immorality}

Moral failure begins with some action identified as noncompliance, but not every instance of noncompliance is constructed and accepted as moral failure. Rather, some instances are heralded as legitimate acts of principled resistance (Sekerka and Bagozzi, 2007), while many others are simply ignored or constructed as lapses of judgment or 
mistakes (Edmondson, 1999).

As with noncompliance, the labeling of an action as immoral is a symbolic accomplishment with potentially significant consequences (Carberry et al., 2018). The literature on organizational legitimacy suggests that there are different audiences that act as the source of such legitimacy evaluations, namely "the internal and external audiences who observe organizations and make legitimacy assessments ... [and] who have the capacity to mobilize and confront the organization, not so much in terms of power but in authority over cultural theory” (Deephouse and Suchman, 2008, p. 54). This conferring of moral legitimacy is achieved in two main realms, namely either within a profession (insiders) or the broader societal community (outsiders). Based on this, we examine a key cultural dimension in which insiders and outsiders differ with respect to whether they are likely to be successful in their constructing of organizational conduct as immoral: the sources of moral legitimacy that underpins the act of labeling.

Sources of moral legitimacy. The previous discussion suggests that for many, if not most, instances of noncompliance, there will be some set of actors motivated to label it as moral failure. The question, thus, becomes why this does not happen more often. At least part of the answer comes from considering that constructing moral failure is a social accomplishment and thus only achievable by actors able to authoritatively represent noncompliance as a more fundamental incongruence with norms. So, even though there may exist actors motivated to construct noncompliance as moral failure, they may be unable to do so unless they have the ability to speak legitimately about the domain in question. Hardy and Phillips (1998, p. 219) give the example of “environmental groups such as Greenpeace [that] can affect public understanding, attract media attention, and pressure the government, because they are understood to be speaking on behalf of the environment”.

In the context of noncompliance and its labeling as moral failure, we are primarily 
concerned with moral legitimacy. Moral legitimacy "reflects a positive normative evaluation of the organization and its activities” that rests on judgements of whether an activity is the right thing to do according to the "audience’s socially constructed value system” (Suchman, 1995, p. 579). Moral legitimacy is thus conferred by the audience, meaning that it refers to the normative domain of propriety rather than self-interest. It is accorded when activities are perceived to be in line with norms in a relevant community (Dart, 2004; Suchman, 1995). Identifying exactly which community has collective authority over such legitimation is a central issue in legitimacy research (Deephouse and Suchman, 2008). Broadly speaking, two main sources of moral legitimacy tend to be articulated in studies of organizations. On the one hand, such legitimacy is often argued to reside with specific legitimacy-granting authorities such as professions. In this case, moral legitimacy can be defined in terms of “congruence with the particular ethics and worldviews of formal professions” (Deephouse and Suchman, 2008, p. 53). Professions have collective authority over what is deemed acceptable behavior among their membership. Violations of acceptable behaviors within a profession will often be either invisible to non-members or of sufficient complexity that nonmembers have little choice but to trust professions to regulate themselves (Neu, 1991). Professions also, as Anteby (2010) argues, probably have more of a vested interest in seeing their activities depicted as morally legitimate than most other actors and so "legitimizing efforts often appear to originate with professionals” (2010, p. 610).

A second perspective is concerned with congruence with the norms of wider societyat-large. That is, moral legitimacy is granted by a variety of actors including the public, the media, and other external experts and commentators. As such, moral legitimacy depends on whether such actors discern congruence between the implied norms of the entity seeking legitimacy and the norms of acceptable behavior in the larger social system (Suchman, 1995). We can usefully distinguish between two types of actors within this system. First, there is the 
general public, i.e those with a non-expert interest in the activities of the legitimacy-seeking entity. Second, there are mediating organizations that have the ability to influence and reflect broader public perceptions and which are often the target of an entity's legitimization attempts, such as the media, scientists, nonprofit organizations, etc. (Elsbach, 1994).

Bringing these perspectives together we can identify acts of noncompliance as occurring in communities characterized by different levels of professionalization. In highly professionalized communities, such as those where noncompliance has occurred among lawyers, accountants, or doctors, it will be those inside this particular community who will be the source of moral legitimacy (Cohen and Dromi, 2018). This might occur, for instance, where a community is associated with highly specialized and tightly controlled forms of knowledge, such that interpretations of noncompliance depend on professional insiders who are seen to have the expertise and wisdom to make such a judgment (Punch, 1996). High degrees of professionalization also enable evaluation of highly contextualized instances of noncompliance whereby an understanding of whether an action is moral or immoral could only be adjudicated by those with very similar professional experience. Such an argument is sometimes made in professions like nursing, where practitioners face a variety of technical, social and political constraints on their actions that can limit their ability to "act morally" (Yarling and McElmurry, 1986). In contrast, in low or non-professionalized communities, the source of moral legitimacy will be outside in the broader environment. Therefore, the determination of whether noncompliance represents moral failure will be made by interested outsiders, either among the general public or within mediating organizations.

\section{Social Construction through Accounts}

We have discussed how actors construct moral failure by labeling an organizational conduct as noncompliant and immoral. What those actors actually do in this process is deployment of a variety of words, metaphors, and referential texts to construct an "account" 
of the conduct in question. We follow Scott and Lyman’s (1968, p. 46) definition of account as “a linguistic device employed whenever an action is subjected to valuative inquiry”. So, for our purposes, accounts represent the linguistic form of how organizational conduct is evaluated with respect to the morals of the community. Literature on the sociology of accounts suggests they are articulations of actors’ interpretations and explanations, and account-making plays a central role in constructing reality and negotiating order in collectives such as organizations and fields (Orbuch, 1997; Polletta et al., 2011). For example, Suddaby and Greenwood (2005) document the role and multiplicity of the accounts that organizational actors deploy to delegitimize an established organizational conduct and to legitimize change.

There are many ways to characterize the content of accounts (Orbuch, 1997). Two dimensions of accounts are of particular importance for our exploration of moral failure: The first dimension is regarding whether the account characterizes the conduct in question as an isolated, idiosyncratic problem in one organization, or as representative of a larger and perhaps more deeply rooted set of problems in the community. This dimension of the account of moral failure can have significant implications for the community as a whole. In some cases, the account can work to maintain or preserve the status quo, by reinforcing both the boundaries of a community and the networks that constitute it. This might occur when the instance of moral failure is represented as an idiosyncratic, personal failure not indicative of a community-level ideological or systemic problem (Carberry et al., 2018). In such cases, the account of moral failure does not challenge the moral standing of the community itself (MacIntyre, 2007). On the other hand, some accounts of moral failure may weaken, undermine or disrupt the social order. This might happen when the moral failure is represented as stemming from a problem in the community itself, as when the community is represented to have failed to inculcate institutions with significant moral charge or establish a 
sufficient regulative order to ensure compliance (Jonsson et al., 2009).

The second dimension is regarding whether the account appeals to institutional forms of sanction, or is devoid of that kind of appeal. It is the distinction between the account that the dispute management literature (Felstiner et al., 1980-1981) calls "naming” and "blaming” in contrast to the account that goes one step further to "claiming” (as in a lawsuit). This dimension too has significant implications for the dynamics of events at the community level. In some cases, the account of moral failure intends to activate an institutional sanction against those responsible. This might happen when moral failure is constructed as a grave, illegal, consequential transgression such as the detailed report of a financial fraud at a large firm. In other cases, however, the account of moral failure does not have any connection to institutional structures that can punish or expunge perpetrators. In these cases, the account acts toward attribution of blame and responsibility to the perpetrators without direct expectation of institutional reaction. An example in this case would be the wave of protests by Google workers in various countries in 2018 to express “outrage” and “discontent” over the company’s handling of sexual harassment (Wakabayashi et al., 2018).

The above two dimensions unpack the symbolic effects of the label of moral failure in the discourse of a community, and makes clear the connections of these effects with symbolic capabilities of actors and symbolic structure of circumstances. In the next section, we draw on the above arguments to distinguish between different accounts of moral failure and to specify which ones are more likely to be used in different circumstances.

\section{Four paths to the social construction of moral failure}

Our arguments highlight two dimensions that influence which actors are likely to be successful in constructing organizational conduct as moral failure and which accounts they are likely to use: vertical vs horizontal surveillance and the degree of professionalization in the community. Together, these distinctions suggest four paths to the social construction of 
moral failure, each led by a distinct set of actors: dominant insiders, watchdog organizations, professional members, and publics. In this section, we argue that the likelihood of each path and the type of account likely to be used depends on an alignment between the conditions associated with labeling an action as noncompliance (the form of surveillance) and the conditions associated with labeling the noncompliance as morally illegitimate (the source of legitimacy). This is not to suggest that other actors will not also be active and that some degree of contestation among different actors and conflicting accounts will occur under such conditions. The point is that a particular set of actors and accounts are most likely to be successful in particular contexts. This is summarized in Table 1 and elaborated on below.

Insert Table 1 about here

\section{The construction of moral failure by dominant insiders: Scapegoating}

Where vertical surveillance is predominant then elite actors will be most likely to identify and evaluate an action as noncompliance. In highly professionalized communities, insiders are the main source of legitimacy. Therefore, we propose that dominant insiders are likely to be the most active and effective in constructing moral failure in this context. By dominant insiders we mean elite actors who are among the most powerful within a professional community, because either they occupy positions of superior authority or their social capital allows them to influence decision making and shape perceptions of the normative acceptability of those decisions within the community.

Dominant insiders can be both individual or collective entities. Professions are not necessarily characterized by homogeneity of values nor behaviors, and hence elite actors within the profession can play a critical role in shaping and enforcing standards and making and communicating legitimacy assessments. Some professions, such as accounting, are dominated by a small group of large organizations ("The Big Four”) who represent a "clearly defined elite center” (Greenwood and Suddaby, 2006) that can exercise authority in 
constructing whether an act of noncompliance represents moral failure according to the norms of the community. Professional associations are also a common manifestation of dominant insiders, in that they "play an important role in monitoring compliance with normatively and coercively sanctioned expectations” (Greenwood et al., 2002, p. 62). Professional associations play an active role in projecting the standards of the community both to insiders and outsiders, providing them with a platform for establishing a dominant discourse over what constitutes moral failure within the profession often with a view to insulating the profession from observation and evaluation from outsiders (Parker, 1994). Thus:

Proposition 1a: In highly professionalized communities with vertical surveillance systems, dominant insiders are likely to be the most active and effective in constructing an organizational conduct as moral failure.

Dominant insiders have an inherent self-interest in dealing with potential violations internally in order to resist oversight and the extension of external regulation (Parker, 1994). Thus, a key goal for dominant insiders in constructing moral failure will be to use the occasion as an opportunity to reinforce, rather than disrupt, the status quo, including the cultural and social structures that are the foundation for their professional power and privilege. For this reason, moral failure will primarily be cast in terms of a rare or unexpected breach of the moral rules of conduct of the community. As such, those identified as committing moral failure will usually be labeled as "bad apples” that need to be dealt with or dismissed in order to preserve the moral order of the community.

This suggests that a form of scapegoating is likely to be used to reassert the moral legitimacy of the professional community and its elites by presenting the problem as one of individual maleficence rather than deeper organizational or institutional failure. Scapegoats are “intentionally created by others in order to 'hide', 'distract', delay', 'avoid’ and 'deny' 
responsibility for problems” and thereby “facilitate group cohesion and identity by clarifying norms” (Brown and Jones, 2000, p. 667). For instance, financial institutions are typically quick to present so-called "rogue traders” as “deviants” or “aberrations” (Wexler, 2010). That is, they are constructed as extreme anomalies from the usual controlled trading environment, even though subsequent analyses tend to uncover entrenched cultures of extreme risk-taking and “profit-driven morality” (Dellaportas et al., 2007; Wexler, 2010). For example, at the trial of Kweku Adoboli, the trader at the heart of the \$2.2bn loss by UBS in 2011, his “extremely unusual” activities were compared with "those of a paedophile, rapist and murderer” even though the company was also later found guilty of "an almighty failure of control” (Pratley, 2012; The Economist, 2012). Therefore, because the private interests of dominant insiders are served by attributing an individualized responsibility to wrongdoing, and their elite position within the profession confers them with the ability to apportion blame and expunge supposed wrongdoers, scapegoating is likely to be their preferred form of account. Thus:

Proposition 1b: Where dominant insiders are most active and effective in constructing organizational conduct as moral failure, their preferred account is scapegoating.

To illustrate this in more detail, we can examine how professional scientific organizations such as universities, publishers and funders deal with cases of scientific fraud. Martin (1992, p. 88) argues that the scientific research profession “contains a host of potentially dubious practices, many of which are considered standard and many others widely tolerated" and that the line between tolerated and not tolerated practices is dependent on the social structure of science. In this example, the institution in question is complex which stems in part from the difficulty in detecting and proving many cases of scientific fraud without an admission of guilt by the scientists in question (Martin, 1992). The complexity of the institutions underpins the tendency for decisions regarding scientific fraud to depend on elite actors, namely: “a relatively small number of scientists and bureaucrats [who] make the 
crucial decisions about research... This group can be called the political scientific elite,” (Martin, 1992, p. 89).

Second, legitimacy with respect to scientific fraud rests predominantly with insiders to the profession, whose interests lay with maintaining the status quo. As Gieryn (1983) argues, scientists engage in a great deal of "boundary work" that includes ensuring that monitoring and enforcement of scientific ethics are largely internal to scientific communities. The motivation for scientific insiders to construct some conduct as moral failure is to reproduce the boundaries and status hierarchies of scientific communities. Martin’s (1992, p. 96) analysis suggests that the relatively rare formal, public prosecutions of scientific fraud "serve as a ritual cleaning of the house of science" in which "all are honest except for a few bad apples" who "suffer a severe, yet just, penalty". Martin (1992, p. 96) argues that this ritual of scapegoating reinforces the status quo by "divid[ing] the scientific community into the guilty and the innocent ... bind[ing] together the majority of members of the community, reaffirming their essential virtue” and "isolat[ing] a few behaviors as corrupt".

\section{The construction of moral failure by watchdog organizations: Prototyping}

In contexts where noncompliance is established by elites through vertical systems of surveillance but where the community in which the wrongdoing takes place has low levels of professionalization, the main source of moral legitimacy will rest with elite outsiders. These elite outsiders can take a variety of forms but can be usefully captured under the label of watchdog organizations. A watchdog organization "keeps an eye on a particular entity or a particular element of community concern, and warns members of the community when potential or actual problems arise” (Community Toolbox, 2012). Although watchdog organizations are often not-for-profit entities (e.g. Baur and Palazzo, 2011), they can also be for-profit enterprises or government agencies. The legitimacy of watchdog organizations, regardless of organizational form, is dependent on their maintaining their outsider identity, at 
least in terms of not benefiting directly from the watched entities or activities (Rao, 1998). For this reason, we consider internal auditors and ombudspersons (such as government agencies assigned to monitor other closely related agencies, or internal corporate auditors) less likely to play watchdog roles in our typology, and more likely to echo the behaviors of dominant insiders. In contrast, the public media can act as a watchdog organization in so far as it is independent from those it surveils, and possesses expert knowledge or specialized information about them (Liebman, 2005). These organizations play an important and highly publicized role in constructing instances of moral failure in contemporary society.

The position of watchdog organizations as elite actors in vertical systems of surveillance means they have access to information not easily accessible to the public and/or have ways of analyzing information that relies on specialized skills or resources. For example, the media revelations of the shady offshore banking practices of the super-rich from the "Panama Papers" relied on dedicated access to 11.5 million leaked documents that took a large team of nearly 400 expert journalists more than a year to analyze before the first stories were published in 2016 (International Consortium of Investigative Journalists, 2016). In addition to their role in surveillance structures, watchdog organizations are also mediators of legitimacy assessments for the general public. They not only provide information about acts of wrongdoing, but also shape public perceptions through their accounts that act as interpretive frames for the public. The media, for example, engages in agenda setting that influences public opinions about organizations (Carroll and McCombs, 2003). Similarly, NGOs and other activist organizations frame actors and actions in specific ways that enhance or challenge their moral legitimacy among the broader public (Haunss, 2007; King, 2008). Therefore, we can summarize as follows: 
Proposition 2a: In low professionalized communities with vertical surveillance systems, watchdog organizations are likely to be the most active and effective in constructing an organizational conduct as moral failure.

As a result of their specialist role and position, watchdog organizations are able to apportion blame in constructing moral failure, but their outsider status leaves them with very limited ability to directly expunge wrongdoers. In contrast to dominant insiders, watchdogs tend to have much less invested in preserving the status quo of the institutions they oversee. Therefore, they may seek to disrupt established roles and practices through their constructions of moral failure. That is, they may seek to use the apportioning of moral blame as an opportunity to propose new actors, practices, and norms into the institutional field. In this sense, constructions of organizational moral failure provide an opportunity for institutional entrepreneurship such as by introducing externally developed programs of action, standards, monitoring and reporting systems to address noncompliance in a more systematic way (Khan et al., 2007).

Watchdog organizations also have their own self-interests to pursue (Baur and Palazzo, 2011). Accounts of moral failure constructed by watchdog organizations represent an opportunity for these organizations to reinforce their own legitimacy and moral authority as elite outsiders. That is, accounts of moral failure can be used to justify their role as independent, authoritative watchdogs with license to investigate, report on wrongdoing, and act as a key source of legitimacy for organizations. Public exposés can thus drive membership and donations, as well as help mobilize collective action aimed at institutional change.

Given these twin goals of institutional disruption and self-legitimation, watchdogs are therefore likely to use constructions of organizational moral failure to point to more systematic organizational or institutional failure that requires constant vigilance and the 
development of effective remedies - which they in turn may seek to provide. As a result, their constructions typically rely on prototyping, namely establishing the deviant actor as typical of an entire category, based on a number of salient features that form the "identity codes" used by audiences to determine category membership (Navis and Glynn, 2010). That is, watchdogs will often target organizations depending on their power and position rather than their relative wrongdoing (Bartley and Child, 2014). Configuring moral failure in terms of an exemplar of a broad category of actors that need to be under surveillance helps keep the media story relatively simple (the actions of organization $\mathrm{X}$ represent a moral failure) while still communicating an underlying message about their own legitimacy (many other organizations are like $\mathrm{X}$ and so we need bigger and better funded watchdogs to oversee them), and about the need for broader institutional change. As Bartley and Child (2014, p. 673) contend: “The linking of systemic problems to particular actors should be seen not as natural or inevitable but as an accomplishment of social movements. Social movements force particular kinds of actors into the spotlight and make them focal points for the redress of grievances and enforcement of rights, with profound implications for trajectories of social change.”

A good example of such prototyping by watchdog organizations concerned the exposés of “sweatshop” working conditions in Nike’s supply chain during the 1990s. Nike came under considerable scrutiny from labor watchdog organizations for using manufacturers in developing countries that employed children and exposed their workers to unsafe and inhumane conditions. The Asian-American Free Labor Association (a branch of the AFLCIO), for example, "spent nearly four years in Indonesia, exposing low wages and poor working conditions in factories producing Nike goods” (Locke, 2003, p. 51). Another incident began with a leaked Ernst \& Young audit of a South Korean contractor of Nike that identified serious health and safety problems, including unsafe exposure to chemicals and dust, and a lack of protective equipment. Locke (2003, p. 53) argues that this incident was 
especially damaging to Nike because "the report came from ... a leading accounting and consulting firm that Nike had hired”.

As a result of these and a number of other constructions by watchdog organizations of Nike’s failure to protect workers in its supplier factories overseas, the company became "the global poster child” for corporate irresponsibility with respect to labor conditions (Zadek, 2004). NGOs and unions used Nike's moral failure to press for institutional change with the result that legislation was proposed in the US Congress that would hold manufacturers and retailers liable for human rights abuses by their contractors, while President Clinton instituted the Apparel Industry Partnership to develop a new set of standards and monitoring aimed at eliminating abuses (Emmelhainz and Adams, 1999). At its launch, the partnership (later to become the Fair Labor Association) included a number of watchdog organizations, including the National Consumer League and the UNITE labor union, along with firms, most notably Nike as the first company to join.

This case illustrates the conditions associated with the construction of moral failure by a watchdog organization: decent working conditions is a complex institution that requires vertical surveillance such as an audit and elite arbiters to verify as noncompliance, while the apparel industry is not highly professionalized and so the main source of legitimacy is external to the industry. By framing the targeted company as a prototype representative of the broader industry rather than just as a moral outlier, watchdogs were able to reinforce their own legitimacy as expert evaluators of compliance as well as extend their reach to developing new institutions of compliance. Thus:

Proposition 2b: Where watchdog organizations are most active and effective in constructing organizational conduct as moral failure, their preferred account is prototyping. 


\section{The construction of moral failure by professional community members: Shaming}

Where horizontal surveillance systems widely disseminate data on the behavior of community members, non-elites will be most likely to identify and evaluate an action as noncompliance. In highly professionalized communities, insiders are the main source of legitimacy. Therefore, we propose that professional members are likely to be the most active and effective in constructing moral failure in this context.

By professional members we mean rank and file community members of a profession rather than those in elite positions of power or authority. Professional members are, “as individuals, largely autonomous when acting professionally and self-regulating as a group” (Brien, 1998, p. 391), whereby “the criteria of admission, legitimate practice and proper conduct are determined and controlled largely by the profession itself” (p. 396). Therefore, given that it takes time for evidence of noncompliance to percolate up the hierarchy, and that members of a professional community may wish to avoid such oversight, they will look to act on the evidence they encounter and self-police their profession. For example, studies of occupational groups have demonstrated that various forms of cheating can become part of the process of socialization and group belonging. As a result, rather than being constructed as moral failure by one’s peers, such acts can be construed as not only morally permissible but even highly valued (Anteby et al., 2016). Hence, rank and file members will often be active in the construction (or otherwise) of moral failure by their professional colleagues. This can be summarized:

Proposition 3a: In highly professionalized communities with horizontal surveillance systems, professional members are likely to be the most active and effective in constructing an organizational conduct as moral failure.

For professional members, moral violations of their community standards can be potential threats to their own moral legitimacy. Hence, their constructions of moral failure 
will typically aim to protect their own position and moral standing while demonizing supposed violators. However, unlike elite professional actors, rank and file members lack the hierarchical power to construct such violators as scapegoats and expunge them from the community (as dominant insiders can). As a result, their best available strategy is typically one of 'shaming' in order to reassert community standards and elicit moral disapproval (Skeel, 2001).

Shaming is a tool used for social control in order to induce desired behavior (Arneson, 2007). Key to the effectiveness of shaming as social control is its embeddedness in a community, in which membership is valuable and thus exit is costly and approval by other members is sought. Shaming involves the identification and publicization of wrongdoers and their actions within such a community. As Skeel (2001: 1816) argues, "the sanction is, in effect, carried out by the offender's community”. Community members withhold approval, without necessarily reverting to formal mechanisms or specifying a concomitant set of penalties or solutions. Should the shaming be successful - that is, a shared understanding emerges of who the violator is and why their behavior is a transgression of the community's ethical standards - penalties and solutions are likely to naturally arise from the community itself.

The legal profession, for example, employs an extensive system of informal regulation of professional norms that is enforced through community-based shaming and reputation-diminishing sanctions. That is standards of professional conduct "are written in the hearts and minds of each lawyer and are reinforced by the monitoring and criticism of other lawyers” (Hazard et al., 1999, p. 19-20). As Wendel (2001) argues, the self-regulatory "shaming rituals" of the legal profession often take the form of "war stories” and gossip among lawyers about bad behavior and subsequent retaliation by fellow lawyers. This retaliation may involve the refusal to extend routine courtesies, a lack of cooperation and the 
erection of administrative hurdles, the denial of referrals, and exclusion from bar association positions, to name a few. Given that professional status is reliant upon professional standing and esteem as well as ongoing cooperation among members, the recurring accounts of these practices can harm the professional reputation of the perceived wrongdoer while reinforcing the norms of the community. In summary:

Proposition 3b: Where professional members are most active and effective in constructing organizational conduct as moral failure, their preferred account is shaming.

\section{The construction of moral failure by publics: Protesting}

The final path to the construction of moral failure we consider is where horizontal surveillance systems enable broad oversight on noncompliance by non-elite actors, but where the community in which the wrongdoing takes place has relatively low levels of professionalization. In this situation, the main source of moral legitimacy will rest with outsiders among the general public and so publics are most likely to be the critical agents advancing dominant constructions of moral failure. By a public, we mean a group of people acting as ordinary members of a community, rather than in any specialized occupational roles. Publics appear in a variety of different shapes, sometimes as relatively unorganized sets of individuals and at other times as more organized social movements. We do not include in this discussion, however, organizations formed to represent public interests, such as watchdog organizations, as discussed above, or state agencies.

As a key source of moral legitimacy, the general public can play a critical role in evaluating organizational behaviors that deviate from expected norms and then constructing (or not) these deviations as moral failure within their relevant communities (MacLean and Behnam, 2010). Constructions of moral failure by publics are likely to be associated with relatively simple institutions, such that no special professional expertise is necessary to 
establish noncompliance, and news of noncompliance can be spread widely among interested parties. Thus, members of the general public will actively engage in an evaluative mode of judgement rather than be passive recipients of the judgements of watchdogs or other actors (Tost, 2011). Therefore:

Proposition 4a: In low professionalized communities with horizontal surveillance systems, publics are likely to be the most active and effective in constructing an organizational conduct as moral failure.

Since publics lack either elite power or insider status their scope for eliciting concrete responses as a result of constructing acts as moral failure is limited. Although publics may engage in attempts to shame offenders, we argue that such attempts are less likely to be successful because of shame's dependence on the commitment of offenders to specific communities that are expressing that shame (Creed et al., 2014). Moreover, there is a higher likelihood that they will want to challenge the status quo and will therefore attribute collective responsibility to a much broader group of actors, rather than attempt individualized shaming campaigns. Hence, for stakeholders such as these who are mostly shut out from other institutionalized channels of change, protest, or "the public expression of discontent" is the primary vehicle for articulating moral failure (King and Soule, 2007). Below, we elaborate on what we mean by the category of protesting in this context.

Protest can take a variety of forms and has been defined in multiple ways. The essential features of protest, however, are that it is a collective action or behavior that is goaloriented and directed at a target (Opp, 2009). Protests capitalize on the outsider status of the publics that deploy them (King and Soule, 2007). That is, in constructing moral failure, they can take the moral high ground and appeal to a much wider audience than is typically the case with insiders.

Protest can serve a variety of goals but evidence suggests that moral protests tend to 
be primarily driven by participants’ desires to express disapproval and advocate a particular set of cultural or moral values rather than preserving or enhancing their own status (Clarke, 1987). In some cases, "such protest is communicative, but the communication is meant largely for the protestor and for his fellow sufferers" rather than to "facilitate certain outcomes” (Talbert, 2012, p. 106). Protest thus may be aimed at disrupting the status quo through attempting to signal a "crisis of legitimacy" with the existing regime (Bratton and Van de Walle, 1997) but not with any clear strategy to effect specific change, but rather as an expression of discontent with prevailing norms of conduct within the target community.

For example, the financial crisis of 2008 did not immediately prompt major protests of any kind (Calhoun, 2013). Insofar as moral failure was constructed around the crisis, it relied on elite outsider watchdogs with expert knowledge of the complex financial instruments that had led to the global meltdown. As Fourcade, Steiner, Streeck, and Woll (2013, p. 602) argue, “expert reflections” about the highly technical mechanics of the crisis identified a range of "good and bad incentives, moral hazard and loopholes" that led to a public response of categorical distinctions between "the corrupt and the honest".

Large-scale protest erupted however in 2011 with the emergence of Los Indignados and the Occupy Wall Street movements. Now, rather than relying on expert analysis, the financial crisis and its aftermath was constructed by a wider public within the framing of inequality and the populist message of "we are the 99\%” (Calhoun, 2013; Shrivastava and Ivanova, 2015; Soule, 2012). Thus, moral failure was constructed not just with respect to specific actors in the financial crisis but at multiple levels - individual, organizational, national, and global system-level - thereby challenging the legitimacy of corporations and of large-scale financial capitalism more generally (Shrivastava and Ivanova, 2015).

In contrast to the trading of exotic financial instruments and the failure of banks and regulators to insulate markets from systemic risk, noncompliance with respect to the norms of 
economic equality can be readily identified through horizontal forms of surveillance; it takes no specific expertise or vantage point to observe inequality in society, and it is experienced directly by non-elites external to the organizations that subsequently become the subjects of critique. Moreover, these experiences of noncompliance are readily communicated through word-of-mouth, slogans, placards and other accouterments of protest (Shrivastava and Ivanova, 2015). Occupy Wall Street therefore "elicited a visceral response from a wide variety of people, because it spoke at once to the giant bonuses of Wall Street traders, the struggles of workers and the middle class to hang on to homes and jobs, and students who would leave university saddled with debt and facing uncertain futures” (Calhoun, 2013). Indeed, the very framing of the $99 \%$ vs the $1 \%$ expressed the outsider status of the various publics engaged in the protest. In summary:

Proposition 4b: Where publics are most active and effective in constructing organizational conduct as moral failure, their preferred account is protest.

\section{Discussion}

Our analysis of the actors and accounts in the social construction of organizational moral failure has a number of important implications for theory and practice. In this section, we discuss our contribution in relation to five key areas: our typology of actors; stages of moral failure; contingent constructions of moral failure; our typology of accounts; and the dynamics of labeling in conditions of institutional pluralism.

\section{Typology of actors}

Studies that touch upon cases of moral failure are often carefully situated in a domain where the identity of the actor who labels an organizational conduct as moral failure is clear from the outset. This presupposed actor is normally chosen from the set of usual suspects ranging from judiciary entities such as regulators, prosecutors, and courts (Bertels et al., 2014; Palmer, 2012; Short and Toffel, 2010) to public media (Benediktsson, 2010; Piazza and 
Perretti, 2015) to organization-level control mechanisms and public relations management (Bartunek et al., 2006; Zavyalova et al., 2012). No matter if such studies have covered the list of usual suspects in a comprehensive or partial manner, the focus of each study on one category of actor effectively means that the question of "who" gets to construct the label of moral failure has often been outside the boundaries of the study. So while scholars have stressed the heterogeneity of the actors involved in the social construction of moral failure (Cooper et al., 2013; Greve et al., 2010), those actors have remained undifferentiated and under-theorized. This problem is also a symptom of how actorhood is taken-for-granted and treated as a given across the whole spectrum of organizational and social sciences (Meyer, 2010; Meyer and Jepperson, 2000). So although the heated debates of the last decades about structure and agency have gradually converged toward the idea of embedded agency at the general level (Green et al., 2009; Zietsma and Lawrence, 2010), research has not paid attention to specification of the core characteristics of embedded actors in particular contexts.

Our arguments rectify the above problem in the specialized domain of moral failure and represent a novel contribution by introducing a typology of actors who are likely to be the agents of the social construction of moral failure under different circumstances. This helps advance the extant literature by giving a name and face to the nameless and faceless notion of embedded agency that is at play in calling organizational moral failures. When this embedded agency becomes demystified as an actor with a name and face, then researchers can begin to uncover the roles and characteristics of that actor and the contours of embeddedness that enable and constrain that actor under different circumstances. This has important implications for several streams of research on organizational moral failure. For example, it contributes to ongoing conversations on targeting of actors in cases of moral failure (Adut, 2008; Graffin et al., 2013) because targeting acts depend not only on the characteristics of the labeled, but also on the attributes and interests of the actor that does the 
targeting and labeling. It also contributes to current discussions on why "many who engage in reprehensible and even unambiguously illegal behavior are never caught” (Greve et al., 2010, p. 85; also see Palmer, 2012; Palmer et al., 2016) by spotlighting who is missing or silent and why. Finally, it helps in gaining a better understanding of some consequential and yet overlooked organizational scenes where the boundaries between moral and amoral are negotiated and drawn (Anteby, 2013; Parmar, 2014).

Our typology further suggests new questions in the domain of organizational moral failure, because knowing "who” is most active and effective in labeling organizational conduct as moral failure reveals an array of new insights about the agency at play that were out of reach before. It portrays a rich image that includes the actors’ commitments, motivations, interests, abilities, action templates, social capital, network positioning, and latitude of action. This enables us to ask a host of new research questions that have the potential to extend the literature in novel ways. For instance, we can ask when and how these actors can be distracted, manipulated, or silenced. Or we can ask when and how multiple sets of actors (stakeholders), with potentially inconsistent views, get involved and interact with one another in the social construction of moral failure. We can explore which mediums of communication and action are more likely to be used by these actors and how the choice of medium can affect their message. We can study how quickly and easily these actors act to label an organizational conduct as moral failure. We can study their intentions, concerns, hopes, fears, and reservations as they engage in the process of labeling. We can address why there is variance in how different actions are perceived and attended to by these actors. These questions and many other inquiries were not possible when the actor was masked behind the notion of embedded agency.

\section{Stages in moral failure}

As set out in Figure 1, the social construction of organizational moral failure can be 
seen as a stage in a broader process of moral failure. This begins with questionable conduct that fails to adhere to the morals of the community, which then may or may not be socially constructed as organizational failure. The relative success of such constructions will then lead to various consequences, such as scandal and stigma, and concomitant responses such as trust repair and rehabilitation. Our analysis contributes new insights and prompts new questions in both of the adjacent stages.

With respect to questionable conduct, the extant literature provides critical insight into the individual and contextual factors likely to prompt unethical or corrupt behavior (Treviño, et al., 2014). Our analysis, however, highlights another crucial category of factors that could precipitate engagement of actors in morally questionable conduct, namely, an actor's knowledge of and control over the points of intervention, prevention, and manipulation for thwarting the labeling process of an organizational conduct as moral failure. Our arguments shed light on the dynamics of the labeling process and highlight the points where exerting power can influence the process. This can help unpack the dynamics of some poorly understood phenomena such as self-sustaining webs of organizational corruption (Ashforth and Anand, 2003; Ashforth et al., 2008).

In the case of consequences and responses of moral failure, our analysis prompts reconsideration of the source or antecedents of scandal and their subsequent diffusion. For instance, prevailing theories of organizational scandal tend to focus on the reputation of targeted actors (Graffin et al., 2013; Zavyalova et al., 2016), responses of stakeholders (Marcus and Goodman, 1991), and scandal’s consequences for the public (Adut, 2008) but do not adequately account for the role of specific actors and accounts in prompting their occurrence and spread. We shed light on when individualized versus collective attributions of failure are likely to be advanced and when constructions of moral failure are likely to focus on actors within or beyond specific professional communities. Hence, these factors can be 
integrated with existing models to better explain why "the reactions to misconduct are not as clean as basic intuition suggests, with punishment being used selectively against some responsible organizations but not others, or against innocent organizations that bear the adverse consequences of misconduct by others” (Greve et al., 2010, p. 85).

Another major contribution to the literature on this stage addresses the response by firms to moral failure. Our analysis points to the motivations and vested interests underlying the construction of moral failure, and how those forces invite various sets of actors to get involved in the episode after a moral failure. This can help in identifying pertinent dimensions of such failures that may influence the type of rehabilitation likely to be proposed by interested actors, and the likelihood of specific interventions being successful (Eberl et al., 2015; Gillespie et al., 2014).

\section{Contingent constructions of moral failure}

Our analysis also sheds light on how the construction of moral failure is contingent on circumstances. Among scholars adopting a more objectivist or normative conception of organizational moral failure (i.e. where failure is regarded as an empirical fact waiting to be discovered or revealed), contingency perspectives have been important in demonstrating that the propensity for organizations to engage in illegal or unethical acts is influenced by context (Baucus and Near 1991; Gabbioneta et al., 2013). This has led to the articulation of predictions of when, where and by which type of organizations moral failure might be most likely. Those adopting a more social constructionist approach to moral failure have also explored the role of context, but more in terms of its role in determining what counts as moral failure within organizations and how it is defined in different environments (e.g. Cooper et al, 2013). However, they have typically stopped short of identifying and categorizing the distinct influences on constructions of moral failure in different contexts, or of providing predictions across contexts. 
Our analysis therefore provides a bridge between these two literatures and provides a unique contingency framework for constructions of moral failure. This enriches the stream of literature concerned with predicting (objective) organizational moral failure by enabling researchers to also predict whether and by whom these failures will actually be called out. It extends the social constructionist stream of literature by providing a more predictive model of which category of actor is more likely to succeed in constructing actions as moral failure, how they do so, and under which type of circumstance.

This also has practical implications for actors seeking to influence the construction of moral failure. That is, since our analysis suggests which actors might be more likely to succeed in providing a dominant account of whether moral failure has occurred in which circumstances, actors can determine in advance whether their accounts are likely to prevail. Moreover, in less propitious contexts, actors can determine who they should collaborate with to increase the likelihood of success in constructing moral failure or which institutional factors they might need to influence to create a more positive context.

\section{Typology of accounts}

Our analysis also contributes to the literature on the role of language and discourse in the social construction of organizational morality. To date, this literature has explored the antecedents, processes and outcomes of moral framing on moral sensemaking and action (Crane, 2000; Palazzo et al., 2012; Sonenshein, 2006, 2007, 2009) as well as the discursive strategies and techniques employed to engender moral legitimation (Bloom and White, 2015; Vaara and Tienar, 2008). Although these studies have been important in identifying how various facets of organizational morality are constructed through accounts they have tended to overlook the specificities of different types of actors and different circumstances in shaping the contours and possibilities of these accounts. In identifying the four types of accounts of moral failure that are likely to be employed in each context, we help unpack in a 
more systematic way the interconnection between particular discursive constructions of organizational morality and the capabilities of actors and the structure of circumstances.

This also provides a richer understanding of the concept of moral failure in that it demonstrates the different ways that a picture of failure can be painted, depending on the relevant actors and circumstances. Thus, moral failure is not simply one side of a binary division (such as moral failure - moral success), but is itself a multi-faceted concept that is open to multiple discursive constructions that in turn prompt a range of interpretive schemas on the part of audiences. Moral failure as constructed through an account of scapegoating, for example, presents an individualized conception of moral failure. This is likely to focus attention on detecting and addressing personal pathologies, prosecuting individuals, and introducing enhanced controls to prevent individual indiscretions (Benediktsson, 2010). It also focuses scholarly attention on micro-level causes of failure such as has been the case following a variety of corporate scandals (Ashforth et al., 2008). In contrast, moral failure constructed through an account of prototyping activates consideration of an entire category of actors (albeit represented by a single representative of that category) and thus prompts consideration of broader reform.

These different responses to different accounts of organizational moral failure are critical. As Barnett (2014) argues, stakeholder response to, or punishment of, organizational moral failure is inconsistent because of the cognitive filtering that stakeholders engage in. The different accounts promulgated by the actors involved will therefore play a key role in determining the level of attention afforded to a particular act of failure and in turn will influence whether and what kind of punishment will follow.

\section{Dynamics of labeling in conditions of institutional pluralism}

Finally, our arguments help us examine and explain the dynamics of labeling organizational conduct under conditions of institutional pluralism. The institutional theory 
literature suggests that many organizations operate in multiple institutional spheres and are thus subject to multiple regulatory rules, normative orders, and cultural logics (Kraatz and Block, 2008). With respect to moral failure, institutional pluralism makes it likely that organizational conduct can be understood and evaluated in relation to multiple moral norms. Thus, under these circumstances, multiple actors can simultaneously engage in constructing the label of moral failure and other competing labels.

We suggest that our framework can help explain and predict which types of actors are likely to confront one another under conditions of institutional pluralism. For instance, consider what are referred to as "Enhanced Interrogation Techniques” (EITs) by United States military organizations, and include walling, prolonged sleep deprivation, cramped confinement, insects placed in the confinement box, dietary manipulation, nudity, water boarding, and other methods of interrogation that inflict severe pain or suffering. There are several heated discussions about the use of these techniques, and if these should be understood as a case of organizational moral failure (Blakeley, 2011). One of the reasons for this controversy is that two different moral norms are often invoked in these discussions. One moral norm is the deontological stance for the absolute prohibition on torture. Upholding this moral implies that EITs are systematic torture of detainees and should be labelled as moral failure. The corresponding surveillance mechanism is horizontal as it relies on leaked information and revelations of the conduct disseminated in informal social networks or public channels of communication. Also, non-elite actors outside the military community have the moral legitimacy to evaluate the conduct and call it a moral failure.

On the other hand, the other moral norm at play here is the utilitarian stance that our moral evaluation of a conduct depends on the consequences that would come out of it. So in some situations, EITs are a necessary evil, and it would be a moral failure to abstain from these techniques when facing an uncooperative detainee with crucial information that can 
save the lives of many people. The corresponding surveillance mechanism is vertical as it relies on sensitive intelligence and confidential information about a potentially dangerous situation collected and reported up through formal hierarchical channels of communication. In addition, only elite actors inside the military community have access to all the available data and most reliable information in order to assess the risks and severity of the situation and see if using these interrogation techniques are warranted or not. Thus, only elite insiders have the moral legitimacy to evaluate the use of EITs and call it a moral failure. Therefore, the above brief analysis and our typology help us explain why the actors who confront one another on the issue of EITs are publics on one side and dominant insiders of military community on the other side (Gronke et al., 2010; Kearns, 2015).

\section{Conclusion}

The seemingly never-ending stream of revelations regarding moral failures of organizations has created serious concerns in public discourse as well as academic research. While scholars have started to study the social construction processes involved in the production, dissemination, and establishment of labels such as organizational moral failure in society, the "actors" whose agency is driving those processes have largely remained in the shadow. This article provides a step forward towards bringing the actor out in the light by developing a theory of "who" gets to call an organizational moral failure. Spotlighting the actors makes it possible to identify different types of "accounts" that they employ under different circumstances to label an organizational conduct as moral failure. The resulting framework, thus, shows the interplay of contingencies, actors, and accounts in the social construction of organizational moral failure.

The presented theoretical framework, however, has to be interpreted within three scope conditions. First, our arguments are focused on the different kinds of actors who work to establish organizational moral failure as a social reality, not as an individual belief. An 
instance of moral failure exists as a social reality to the extent it exists in the discourse of a community, independently of whether individuals in that community believe in it. Second, our social constructionist approach to moral failure is best suited to those instances where there is fragmentation or dissensus with respect to the morality of an action. Such a condition might stem from conflict over the facts (what actions were taken with what outcomes), the intentions or responsibility of the actors involved, and/or the rightness or wrongness of a particular action. Finally, establishing an account whereby an organizational conduct is labeled moral failure does not rule out the existence of other accounts regarding that organizational conduct. It simply means that the account of moral failure has come to be the principal account used to make sense of the organizational conduct in question. In most situations, this principal account will be subsequently taken up and reiterated using various types of accounts by a larger set of actors. 
Who Calls it?

This article does not contain any studies with human participants or animals performed by any of the authors. 


\section{References}

Adut, A. (2008). On Scandal: Moral Disturbances in Society, Politics, and Art. New York: Cambridge University Press.

Angus, L. B. (1993). Masculinity and women teachers at Christian Brothers College. Organization Studies 14, 235-260.

Anteby, M. (2010). Markets, morals, and practices of trade: Jurisdictional disputes in the US commerce in cadavers. Administrative Science Quarterly 55, 606-638.

Anteby, M. (2013). Manufacturing Morals: The Values of Silence in Business School Education. Chicago: University of Chicago Press.

Anteby, M., Chan, C. K. \& DiBenigno, J. (2016). Three lenses on occupations and professions in organizations: becoming, doing, and relating. The Academy of Management Annals 10, 183-244.

Arneson, R. J. (2007). Shame, stigma, and disgust in the decent society. Journal of Ethics 11, 31-63.

Ashforth, B. E. and Anand, V. (2003). The normalization of corruption in organizations. In R. M. Kramer and B. Staw (eds.) Research in Organizational Behavior (vol. 25) (pp. 152). Amsterdam: Elsevier.

Ashforth, B. E., Gioia, D. A., Robinson, S. L. and Treviño, L. K. (2008). Re-viewing organizational corruption. Academy of Management Review 33, 670-684.

Azoulay, P., Bonatti, A., and Krieger, J. L. (2017). The career effects of scandal: Evidence from scientific retractions. Research Policy 46(9), 1552-1569.

Barker, J. R. (1993). Tightening the iron cage: Concertive control in self-managing teams. Administrative Science Quarterly 38, 408-437.

Barnett, M. L. (2014). Why stakeholders ignore firm misconduct: A cognitive view. Journal of Management 40, 676-702. 
Bartley, T. and Child, C. (2014). Shaming the corporation: The social production of targets and the anti-sweatshop movement. American Sociological Review 79, 653-679.

Bartunek, J. M., Hinsdale, M. A. and Keenan, J. F. (2006). Church Ethics and Its Organizational Context: Learning from the Sex Abuse Scandal in the Catholic Church. Oxford: Rowman \& Littlefield.

Baucus, M. S. and Near, J. P. (1991). Can illegal corporate behavior be predicted? An event history analysis. Academy of Management Journal 34, 9-36.

Baur, D. \& Palazzo, G. (2011). The moral legitimacy of NGOs as partners of corporations. Business Ethics Quarterly 21, 579-604.

Benediktsson, M. O. (2010). The deviant organization and the bad apple CEO: Ideology and accountability in media coverage of corporate scandals. Social Forces 88, 2189-2216.

Bennett, R. J. and Robinson, S. L. (2003). The past, present, and future of workplace deviance research. In J. Greenberg (ed.) Organizational behavior: The state of the science (2 ${ }^{\text {nd }}$ edition) (pp. 247-281). Mahwah, NJ: Lawrence Erlbaum.

Bertels, S., Cody, M. and Pek, S. (2014). A responsive approach to organizational misconduct: Rehabilitation, reintegration, and the reduction of reoffence. Business Ethics Quarterly 24, 343-370.

Blakeley, R. (2011). Dirty hands, clean conscience? The CIA inspector general’s investigation of "Enhanced Interrogation Techniques" in the war on terror and the torture debate. Journal of Human Rights 10, 544-561.

Bloom, P. N. and White, P. J. (2015). The moral work of subversion. Human Relations 69(1), $5-31$.

Bratton, M. and Van de Walle, N. (1997). Democratic Experiments in Africa: Regime Transitions in Comparative Perspective. Cambridge: Cambridge University Press. Brien, A. (1998). Professional ethics and the culture of trust. Journal of Business Ethics 17, 
391-409.

Brown, A. D. and Jones, M. (2000). Honourable members and dishonourable deeds: Sensemaking, impression management and legitimation in the 'Arms to Iraq Affair' Human Relations 53, 655-689.

Calhoun, C. (2013). Occupy Wall Street in perspective. British Journal of Sociology 64, 2638.

Carberry, E. J., Engelen, P. J., and Van Essen, M. (2018). Which Firms Get Punished for Unethical Behavior? Explaining Variation in Stock Market Reactions to Corporate Misconduct. Business Ethics Quarterly 28(2), 119-151.

Carroll, C. E., and McCombs, M. (2003). Agenda-setting effects of business news on the public's images and opinions about major corporations. Corporate Reputation Review 6, 36-46.

Clarke, A. (1987). Moral protest, status defence and the anti-abortion campaign. British Journal of Sociology 38, 235-253.

Cohen, A. C., and Dromi, S. M. (2018). Advertising morality: Maintaining moral worth in a stigmatized profession. Theory and Society 47(2), in press.

Community Toolbox. (2012). Acting as a watchdog. http://ctb.ku.edu/en/table-ofcontents/advocacy/advocacy-research/act-as-watchdog/main

Cooper, D. J., Dacin, T. and Palmer, D. A. (2013). Fraud in accounting, organizations and society: Extending the boundaries of research. Accounting, Organizations \& Society 38, 440-457.

Crane, A. (2000). Corporate greening as amoralization. Organization Studies 21(4), 673-696.

Creed, D. W. E., Hudson, B. A., Okhuysen, G. A., and Smith-Crowe, K. (2014). Swimming in a sea of shame: incorporating emotion into explanations of institutional reproduction and change. Academy of Management Review 39(3), 275-301. 
Crossley, N. (2002). Global anti-corporate struggle: A preliminary analysis. British Journal of Sociology 53, 667-691.

Daboub, A. J., Rasheed, A. M. A., Priem, R. L., Gray, D. A. (1995). Top management team characteristics and corporate illegal activity. Academy of Management Review 20, 138-170.

Dart, R. (2004). The legitimacy of social enterprise. Nonprofit Management \& Leadership $14,411-424$.

De Maria, W. (2010). After the scandal - Recovery options for damaged organizations. Journal of Management \& Organization 16, 66-82.

Deephouse, D. L. and Suchman, M. (2008). Legitimacy in organizational institutionalism. In R. Greenwood, C. Oliver, K. Sahlin, and R. Suddaby (eds.), The SAGE handbook of organizational institutionalism (pp. 49-77). London: Sage.

Dellaportas, S., Cooper, B. J. and Braica, P. (2007). Leadership, culture and employee deceit: The case of the National Australia Bank. Corporate Governance: An International Review 15, 1442-1452.

Dey, P. and Teasdale, S. (2016). The tactical mimicry of social enterprise strategies: Acting 'as if' in the everyday life of third sector organizations. Organization 23, 485-504.

Durand, R. and Vergne, J. (2015). Asset divestment as a response to media attacks in stigmatized industries. Strategic Management Journal 36, 1205-1223.

Dyck, A., Morse, A. and Zingales, L. (2010). Who blows the whistle on corporate fraud? Journal of Finance 65, 2213-2253.

Eberl, P., Geiger, D., Aßländer, M. S. (2015). Repairing trust in an organization after integrity violations: The ambivalence of organizational rule adjustments. Organization Studies 36, 1205-1235.

Edmondson, A. (1999). Psychological safety and learning behavior in work teams. 
Administrative Science Quarterly 44, 350-383.

Elsbach,D. (1994). Managing organizational legitimacy in the California cattle industry: The construction and effectiveness of verbal accounts. Administrative Science Quarterly 39, 57-88.

Emmelhainz, M. A. and Adams, R. J. (1999). The apparel industry response to "sweatshop" concerns: A review and analysis of codes of conduct. Journal of Supply Chain Management 35, 51-57.

Felstiner, W. L. F., Abel, R. L., and Sarat, A. (1980-1981). The emergence and transformation of disputes: Naming, blaming and claiming. Law \& Society Review 15, 631-654.

Fourcade, M., Steiner, P., Streeck, W. and Woll, C. (2013). Moral categories in the financial crisis. Socio-Economic Review 11, 601-627.

Fox-Wolfgramm, S. J., Boal, K. B. and Hunt, J. G. (1998). Organizational adaptation to institutional change: A case study of first-order change in prospector and defender banks. Administrative Science Quarterly 43, 87-126.

Gabbioneta, C., Greenwood, R., Mazzola, P. and Minoja, M. (2013). The influence of the institutional context on corporate illegality. Accounting, Organizations \& Society 38, 484-504.

Gandy, O. H. (1989). The surveillance society: Information technology and bureaucratic social control. Journal of Communication 39, 61-76.

Gieryn, T. F. (1983). Boundary-work and the demarcation of science from non-science: Strains and interests in professional ideologies of scientists. American Sociological Review 48, 781-795.

Gillespie, N., Dietz, G., and Lockey, S. (2014). Organizational reintegration and trust repair after an integrity violation: A case study. Business Ethics Quarterly 24, 371-410. 
Goodstein, J., Butterfield, K. D., Pfarrer, M. D., and Wicks, A. C. (2014). Individual and organizational reintegration after ethical or legal transgressions: Challenges and opportunities. Business Ethics Quarterly 24, 315-342.

Goodstein, J. D. and Wicks, A. C. (2007). Corporate and stakeholder responsibility: Making business ethics a two-way conversation. Business Ethics Quarterly 17, 375-398.

Graffin, S. D., Bundy, J., Porac, J. F., Wade, J. B., and Quinne, D. P. (2013). Falls from grace and the hazards of high status: The 2009 British MP expense scandal and its impact on parliamentary elites. Administrative Science Quarterly 58, 313-345.

Granovetter, M. (2007). The social construction of corruption. In V. Nee and R. Swedberg (eds.), On Capitalism (pp. 152-172). Stanford: Stanford University Press.

Green, S. E., Li, Y. and Nohria, N. (2009). Suspended in self-spun webs of significance: A rhetorical model of institutionalization and institutionally embedded agency. Academy of Management Journal 52, 11-36.

Greenwood, R. and Suddaby, R. (2006). 'Institutional entrepreneurship in mature fields: The big five accounting firms. Academy of Management Journal 49, 27-48.

Greenwood, R., Suddaby, R., and Hinings, C. R. (2002). Theorizing change: The role of professional associations in the transformation of institutionalized fields. Academy of Management Journal 45, 58-80.

Greve, H., Palmer, D. and Pozner, J. (2010). Organizations gone wild: The causes, processes, and consequences of organizational misconduct. Academy of Management Annals 4, 53-107.

Gronke, P., Rejali, D., Drenguis, D., Hicks, J., Miller, P. and Nakayama, B. (2010). U.S. public opinion on torture, 2001-2009. PS: Political Science and Politics 43, 437-444.

Hardy, C. and Phillips, N. (1998). Strategies of engagement: Lessons from the critical examination of collaboration and conflict in an interorganizational domain. 
Organization Science 9, 217-230.

Haunss, S. (2007). Challenging legitimacy: Repertoires of contention, political claimsmaking, and collective action frames. In A. Hurrelmann, S. Schneider, and J. Steffek (eds.) Legitimacy in an age of global politics (pp. 156-172). New York: Springer.

Hazard, G. C., Jr., Koniak, S. P., and Cramton, R. C. (1999). The Law and Ethics of Lawyering. 3rd edition. New York: Foundation Press.

Holm, P. (1995). The dynamics of institutionalization: Transformation processes in Norwegian fisheries. Administrative Science Quarterly 40, 398-422.

International Consortium of Investigative Journalists. (2016). Giant Leak of Offshore Financial Records Exposes Global Array of Crime and Corruption. International Consortium of Investigative Journalists, https://panamapapers.icij.org/20160403panama-papers-global-overview.html.

Janney, J. J., and Gove, S. (2017). Firm linkages to scandals via directors and professional service firms: Insights from the backdating scandal. Journal of Business Ethics 140, $65-79$.

Jonsson, S., Greve, H. R. and Fujiwara-Greve, T. (2009). Undeserved loss: The spread of legitimacy loss to innocent organizations in response to reported corporate deviance. Administrative Science Quarterly 54, 195-228.

Kaptein, M. (2008). Developing a measure of unethical behavior in the workplace: A stakeholder perspective. Journal of Management 34, 978-1008.

Kearns, E. M. (2015). The study of torture: Why it persists, why perceptions of it are malleable, and why it is difficult to eradicate. Laws 4, 1-15.

Khan, F. R., Munir, K. A. and Willmott, H. (2007). A dark side of institutional entrepreneurship: Soccer balls, child labour and postcolonial impoverishment. Organization Studies 28, 1055-1077. 
King, B. (2008). A social movement perspective of stakeholder collective action and influence. Business \& Society 47, 21-49.

King, B. G. and Soule, S. A. (2007). Social movements as extra-institutional entrepreneurs: The effect of protests on stock price returns. Administrative Science Quarterly 52, 413-442.

Kraatz, M. S. and Block, E. S. (2008). Organizational implications of institutional pluralism. In R. Greenwood, C. Oliver, K. Sahlin, and R. Suddaby (eds.) The SAGE Handbook of Organizational Institutionalism (pp. 243-275). London: Sage.

Kuhn, T. and Ashcraft, K. L. (2003). Corporate scandal and the theory of the firm: Formulating the contributions of organizational communication studies. Management Communication Quarterly 17, 20-57.

Lange, D. and Washburn, N. T. (2012). Understanding attributions of corporate social irresponsibility. Academy of Management Review 37, 300-326.

Lawrence, T. B. (2008). Power, institutions and organizations. In R. Greenwood, C. Oliver, K. Sahlin, and R. Suddaby (eds.) Sage handbook of organizational institutionalism (pp. 170-197). London: Sage.

Lawrence, T. B. and Suddaby, R. (2006). Institutions and institutional work. In S. R. Clegg, C. Hardy, T. B. Lawrence, and W. R. Nord (eds.) Handbook of organization studies (Second Volume) (pp. 215-254). London: Sage.

Leblebici, H., Salancik, G. R., Copay, A. and King, T. (1991). Institutional change and the transformation of interorganizational fields: An organizational history of the U.S. radio broadcasting industry. Administrative Science Quarterly 36, 333-363.

Liebman, B. L. (2005). Watchdog or demagogue? The media in the Chinese legal system. Columbia Law Review 105, 1-157.

Locke, R. M. (2003). The promise and perils of globalization: The case of Nike. In T. A. 
Kochan and R. L. Schmalensee (eds.) Management: Inventing and delivering its future (pp. 39-70). Cambridge, MA: MIT Press.

Logue, D. M. and Clegg, S. R. (2015). Wikileaks and The News of the World: The political circuitry of labeling. Journal of Management Inquiry 24, 394-404.

MacIntyre, A. (2007). After Virtue. London: Duckworth.

MacLean, T. L. (2008). Framing and organizational misconduct: A symbolic interactionist study. Journal of Business Ethics 78, 3-16.

MacLean, T. L., and Behnam, M. (2010). The dangers of decoupling: The relationship between compliance programs, legitimacy perceptions, and institutionalized misconduct. Academy of Management Journal 53(6), 1499-1520.

Marcus, A. A. and Goodman, R. S. (1991). Victims and shareholders: The dilemmas of presenting corporate policy during a crisis. Academy of Management Journal 34, 281-305.

Martin, B. (1992). Scientific fraud and the power structure of science. Prometheus 10, 83-98.

Meyer, J. W. (2010). World society, institutional theories, and the actor. Annual Review of Sociology 36, 1-20.

Meyer, J. W. and Jepperson, R. L. (2000). The “actors” of modern society: The cultural construction of social agency. Sociological Theory 18, 100-120.

Meyer, J. W. and Scott, W. R. (Eds.) (1983). Organizational Environments: Ritual and Rationality. Beverly Hills, CA: Sage.

Miceli, M. P., Near, J. P., and Dworkin, T. M. (2008). Whistle-Blowing in Organizations. New York, NY: Routledge.

Miller, J. (1994). The social control of religious zeal: A study of organizational contradictions. New Brunswick, NJ: Rutgers University Press.

Mitchell, T. R., Daniels, D., Hopper, H., George-Falvy, J., and Ferris, G. R. (1996). 
Perceived correlates of illegal behavior in organizations. Journal of Business Ethics 15, 439-455.

Morrill, C., Zald, M. N. and Rao, H. (2003). Covert political conflict in organizations: Challenges from below. Annual Review of Sociology 29, 391-415.

Navis, C. and Glynn, M. A. (2010). How new market categories emerge: Temporal dynamics of legitimacy, identity, and entrepreneurship in satellite radio, 1990-2005. Administrative Science Quarterly 55, 439-471.

Neu, D. (1991). Trust, impression management and the public accounting profession. Critical Perspectives on Accounting 2, 295-313.

Nielsen, R. P. (2000). The politics of long-term corruption reform: A combined social movement and action-learning approach. Business Ethics Quarterly 10, 305-317.

Opp, K. D. (2009). Theories of Political Protest and Social Movements: A Multidisciplinary Introduction, Critique, and Synthesis. London and New York: Routledge.

Orbuch, T. L. (1997). People's accounts count: The sociology of accounts. Annual Review of Sociology 23, 455-478.

Palazzo, G., Krings, F. and Hoffrage, U. (2012). Ethical blindness. Journal of Business Ethics 109, 323-338.

Palmer, D. (2012). Normal Organizational Wrongdoing: A Critical Analysis of Theories of Misconduct in and by Organizations. Oxford: Oxford University Press.

Palmer, D., Smith-Crowe, K. and Greenwood, R. (2016). The imbalances and limitations of theory and research on organizational wrongdoing. In D. Palmer, R. Greenwood, and K. Smith-Crowe (eds.) Organizational wrongdoing: Key perspectives and new directions (pp. 1-16). Cambridge: Cambridge University Press.

Parker, L. D. (1994). Professional accounting body ethics: In search of the private interest. Accounting, Organizations and Society 19, 507-525. 
Parmar, B. (2014). From intrapsychic moral awareness to the role of social disruptions, labeling, and actions in the emergence of moral issues. Organization Studies 35, 1101-1126.

Piazza, A. and Perretti, F. (2015). Categorical stigma and firm disengagement: Nuclear power generation in the United States, 1970-2000. Organization Science 26, 724-742.

Polletta, F., Chen, P. C. B., Gardner, B. G., and Motes, A. (2011). The sociology of storytelling. Annual Review of Sociology 37, 109-130.

Pratley, N. (2012). UBS guilty of almighty failure of control over rogue trader Kweku Adoboli. The Guardian, November 26, 2012: https://www.theguardian.com/business/nils-pratley-on-finance/2012/nov/26/ubsfailure-control-rogue-trader-kweku-adoboli

Prechel, H. and Morris, T. (2010). The effects of organizational and political embeddedness on financial malfeasance in the largest U.S. corporations: Dependence, incentives, and opportunities. American Sociological Review 75, 331-354.

Punch, M. (1996). Dirty business: Exploring corporate misconduct: Analysis and cases. London: Sage.

Rao, H. (1998). Caveat emptor: The construction of nonprofit consumer watchdog organizations. American Journal of Sociology 103, 912-961.

Roulet, T. (2015). “What good is Wall Street?” Institutional contradiction and the diffusion of the stigma over the finance industry. Journal of Business Ethics 130(2), 389-402.

Scott, W. R. (2014). Institutions and Organizations: Ideas, Interests, and Identities (4 ${ }^{\text {th }}$ edition). London: Sage.

Scott, M. B. and Lyman, S. M. (1968). Accounts. American Sociological Review 33, 46-62.

Sekerka, L. E. and Bagozzi, R. P. (2007). Moral courage in the workplace: moving to and from the desire and decision to act. Business Ethics: A European Review 16, 132-149. 
Selznick, P. (1957). Leadership in administration. Berkeley, CA: University of California Press.

Selznick, P. (1992). The moral commonwealth: Social theory and the promise of community. Berkeley: University of California Press.

Sewell, G. (1998). The discipline of teams: The control of team-based industrial work through electronic and peer surveillance. Administrative Science Quarterly 43, 397428.

Sewell, G. (2012). Organizations, employees and surveillance. In K. Ball, K. Haggerty, and D. Lyon (eds.) Routledge Handbook of Surveillance Studies (pp. 303-312). New York, NY: Routledge.

Sewell, G. and Wilkinson, B. (1992). 'Someone to watch over me’: Surveillance, discipline and the just-in-time labour process. Sociology 26, 271-289.

Shadnam, M. and Lawrence, T. B. (2011). Understanding widespread misconduct in organizations: An institutional theory of moral collapse. Business Ethics Quarterly 21, 379-407.

Sharkey, A. J. (2014). Categories and organizational status: The role of industry status in the response to organization deviance. American Journal of Sociology 119, 1380-1433.

Short, J. L. and Toffel, M. W. (2010). Making self-regulation more than merely symbolic: The critical role of the legal environment. Administrative Science Quarterly 55, 361396.

Shrivastava, P. and Ivanova, O. (2015). Inequality, corporate legitimacy and the Occupy Wall Street movement. Human Relations 68, 1209-1231.

Skeel, D. A., Jr. (2001). Shaming in corporate law. University of Pennsylvania Law Review 149, 1811-1868.

Sonenshein, S. (2006). Crafting social issues at work. Academy of Management Journal 49, 
$1158-1172$.

Sonenshein, S. (2007). The role of construction, intuition, and justification in responding to ethical issues at work: The sensemaking-intuition model. Academy of Management Review 32, 1022-1040.

Sonenshein, S. (2009). Emergence of ethical issues during strategic change implementation. Organization Science 20, 223-239.

Soule, S. A. (2012). Social movements and markets, industries, and firms. Organization Studies 33, 1715-1733.

Suchman, M. C. (1995). Managing legitimacy: Strategic and institutional approaches. Academy of Management Review 20, 571-610.

Suddaby, R. and Greenwood, R. (2005). Rhetorical strategies of legitimacy. Administrative Science Quarterly 50, 35-67.

Talbert, M. (2012). Moral competence, moral blame, and protest. Journal of Ethics 16, 89109.

The Economist (2012). Blame the institution, not the individual. The Economist, November 13, 2012: https://www.economist.com/blogs/schumpeter/2012/11/ubs’s-rogue-tradertrial

Tompkins, P. K. and Cheney, G. (1985). Communication and unobtrusive control in contemporary organizations. In R. McPhee and P. K. Tompkins (eds.) Organizational communication: Traditional themes and new directions (Vol. 13) (pp. 179-210). Beverly Hills, CA: Sage.

Tost, L. P. (2011). An integrative model of legitimacy judgments. Academy of Management Review 36, 686-710.

Tracey, P. and Phillips, N. (2016). Managing the consequences of organizational stigmatization: Identity work in a social enterprise. Academy of Management Journal 
59, 740-765.

Treviño, L. K. \& Nelson, K. A. (2007). Managing Business Ethics. Hoboken, NJ: Wiley

Treviño, L. K., den Nieuwenboer, N. A. and Kish-Gephart, J. J. (2014). (Un)Ethical behavior in organizations. Annual Review of Psychology 65, 635-660.

Vaara, E. and Tienari, J. (2008). A discursive perspective on legitimation strategies in multinational corporations. Academy of Management Review 33, 985-993.

Vergne, J. (2012). Stigmatized categories and public disapproval of organizations: A mixedmethods study of the global arms industry, 1996-2007. Academy of Management Journal 55, 1027-1052.

Waegel, W. B., Ermann, M. D., and Horowitz, A. M. (1981). Organizational responses to imputations of deviance. The Sociological Quarterly 22, 43-55.

Wakabayashi, D., Griffith, E., Tsang, A., \& Conger, K. (2018). Google Walkout: Employees Stage Protest Over Handling of Sexual Harassment. New York Times, November 1, 2018, https://www.nytimes.com/2018/11/01/technology/google-walkout-sexualharassment.html

Wendel, W. B. (2001). Nonlegal regulation of the legal profession: Social norms in professional communities. Vanderbilt Law Review 54, 1953-2055.

Wexler, M. N. (2010). Financial edgework and the persistence of rogue traders. Business and Society Review 115, 1-25.

Wiesenfeld, B. M., Wurthmann, K. A. and Hambrick, D. C. (2008). The stigmatization and devaluation of elites associated with corporate failures: A process model. Academy of Management Review 33, 231-251.

Yarling, R. M. and McElmurry, B. J. (1986). The moral foundations of nursing. Advances in Nursing Science 8, 63-74.

Zadek, S. (2004). The path to corporate responsibility. Harvard Business Review 82, 125- 
132.

Zavyalova, A., Pfarrer, M. D., Reger, R. K. and Hubbard, T. D. (2016). Reputation as a benefit and a burden? How stakeholders' organizational identification affects the role of reputation following a negative event. Academy of Management Journal 59, 253276.

Zavyalova, A., Pfarrer, M. D., Reger, R. K. and Shapiro, D. L. (2012). Managing the message: The effects of firm actions and industry spillovers on media coverage following wrongdoing. Academy of Management Journal 55, 1079-1101.

Zietsma, C. and Lawrence, T. B. (2010). Institutional work in the transformation of an organizational field: The interplay of boundary work and practice work. Administrative Science Quarterly 55, 189-221. 
Figure 1: Stages in Organizational Moral Failure

\begin{tabular}{|c|c|c|}
\hline $\begin{array}{l}\text { Not Adhering to } \\
\text { Morals of Community }\end{array}$ & $\begin{array}{c}\text { Social Construction of } \\
\text { Moral Failure }\end{array}$ & $\begin{array}{l}\text { Consequences and } \\
\text { Responses }\end{array}$ \\
\hline $\begin{array}{l}\text { All the processes that make } \\
\text { organizations engage in a morally } \\
\text { questionable conduct including } \\
\text { various sorts of precipitating } \\
\text { conditions }\end{array}$ & $\begin{array}{l}\text { All the processes that take an } \\
\text { organizational conduct and } \\
\text { socially construct it as a moral } \\
\text { failure by constructing it as } \\
\text { noncompliance and immoral }\end{array}$ & $\begin{array}{l}\text { All the processes that organizations } \\
\text { engage in to deal with the moral } \\
\text { failure including avoiding the taint, } \\
\text { restructuring the field, and regaining } \\
\text { the stakeholders' trust }\end{array}$ \\
\hline $\begin{array}{l}\text { Core research question: } \\
\text { How do organizational members act } \\
\text { contrary to morals? Under which } \\
\text { circumstances? Which factors play } \\
\text { a significant role? }\end{array}$ & $\begin{array}{l}\text { Core research question: } \\
\text { - How is an organizational conduct } \\
\text { constructed as moral failure? Under } \\
\text { which circumstances? Which } \\
\text { factors play a significant role? }\end{array}$ & $\begin{array}{l}\text { Core research question: } \\
\text { - How does an organization recover } \\
\text { from moral failure? Under which } \\
\text { circumstances? Which factors play } \\
\text { a significant role? }\end{array}$ \\
\hline $\begin{array}{l}\text { Sample literatures that typically } \\
\text { focus on this stage: } \\
\text { - Organizational misconduct } \\
\text { - Unethical behavior } \\
\text { - Corruption } \\
\text { - Antecedents of deviance }\end{array}$ & $\begin{array}{l}\text { Sample literatures that typically } \\
\text { focus on this stage: } \\
\text { - Labeling }\end{array}$ & $\begin{array}{l}\text { Sample literatures that typically } \\
\text { focus on this stage: } \\
\text { - Scandal } \\
\text { - Trust repair } \\
\text { - Rehabilitation } \\
\text { - Responses to deviance }\end{array}$ \\
\hline
\end{tabular}


Table 1: A Framework of Different Contingencies, Actors, and Accounts in Organizational Moral Failure

\begin{tabular}{|c|c|c|c|}
\hline \multirow{6}{*}{$\begin{array}{l}\text { Degree of } \\
\text { professionalization } \\
\text { of community } \\
\text { where } \\
\text { noncompliance } \\
\text { takes place }\end{array}$} & \multicolumn{3}{|c|}{ Form of surveillance to identify noncompliance } \\
\hline & \multicolumn{2}{|r|}{ Vertical } & \\
\hline & High & $\begin{array}{l}\text { Key Actors = Dominant Insiders } \\
\text { - aim to reinforce status quo of community } \\
\text { involved in noncompliance } \\
\text { - aim to reinforce own position of power and } \\
\text { privilege } \\
\text { - attribute individualized responsibility } \\
\text { - ability to apportion blame and expunge } \\
\text { perpetrators }\end{array}$ & $\begin{array}{l}\text { Key Actors = Professional Members } \\
\text { - aim to reinforce status quo of community } \\
\text { involved in noncompliance } \\
\text { - aim to preserve own moral legitimacy } \\
\text { - attribute individualized responsibility } \\
\text { - ability to apportion blame but limited ability } \\
\text { to expunge perpetrators }\end{array}$ \\
\hline & & Key Account = Scapegoating & Key Account $=$ Shaming \\
\hline & Low & $\begin{array}{l}\text { Key Actors = Watchdog Organizations } \\
\text { - aim to challenge status quo of community } \\
\text { involved in noncompliance } \\
\text { - aim to reinforce own legitimacy and moral } \\
\text { authority } \\
\text { - attribute collective responsibility } \\
\text { (extrapolated from individual) } \\
\text { - ability to apportion blame and propose } \\
\text { solutions }\end{array}$ & $\begin{array}{l}\text { Key Actors = Publics } \\
\text { - aim to challenge status quo of community } \\
\text { involved in noncompliance } \\
\text { - aim to express own moral values } \\
\text { - attribute collective responsibility } \\
\text { - ability to apportion blame, but limited ability } \\
\text { to propose solutions or expunge perpetrators }\end{array}$ \\
\hline & & Key Account $=$ Prototyping & Key Account $=$ Protesting \\
\hline
\end{tabular}

